\title{
EVALUASI AMDAL PEMBANGUNAN GEDUNG 10 LANTAI DI PUSAT KOTA BANDUNG
}

\author{
Environmental Impact Assessment Evaluation Of 10 Floors Building In Center Of Bandung
}

\author{
Rina Marina Masri \\ Program Studi Teknik Sipil DPTS FPTK UPI Bandung \\ email: rinammasri@gmail.com
}

\begin{abstract}
Uncontrolled development in Bandung made impact on the high levels of environmental pollution. This suggests that the EIA could not be used as an instrument for disaster mitigation and complementary to environment. The objectives of feasibility studies: (1) evaluate the terms of reference for the construction of a 10-storey building in the center of Bandung, (2) evaluate the results of the environmental impact assessment (EIA), (3) evaluate the EMP and EMOP, (4) evaluate the implementation of the EIA 10-storey building in the center of Bandung City in terms of timeliness, accuracy and precision of the results of actions to mitigate negative impacts and enhance positive impacts. Problem-solving methods with descriptive and analytical techniques of content analysis (content analysis). Results of the study: 1) TOR documents prepared by consultants with expert personnel number is less than required so that the consultant was not able to examine carefully, holistic and integral in preparing the EIA document, (2) EIA studies tend to lack information of environmental components that negatively and positively on the environment, (3) EMP and EMOP consultants compilers do not know exactly commitment and coordination mechanism legally binding institutional environmental management plan to mitigate negative impacts and enhance positive impacts. (4) The product of EIA only is stored documents without a doubt if the indicators EIA, EMP and EMOP violated.
\end{abstract}

Keywords: Evaluation, EIA, TOR, EA, EMP, EMOP

\begin{abstract}
Abstrak
Pembangunan yang tidak terkendali di Kota Bandung berdampak pada tingginya tingkat pencemaran lingkungan. Hal ini mengisyaratkan bahwa AMDAL belum dapat dijadikan sebagai salah satu instrument untuk mitigasi bencana serta pelengkap bagi kelayakan lingkungan.Tujuan penelitian: (1) mengevaluasi dokumen kerangka acuan pembangunan gedung 10 lantai di pusat Kota Bandung, (2) mengevaluasi hasil analisis dampak lingkungan (ANDAL), (3) mengevaluasi RKL dan RPL, (4) mengevaluasi implementasi AMDAL pembangunan gedung 10 lantai di pusat Kota Bandung ditinjau dari ketepatan waktu, ketepatan tindakan dan ketepatan hasil guna mengurangi dampak negatif serta meningkatkan dampak positif. Metode pemecahan masalah dengan deskriptif dan teknik analisis analisis isi (content analysis). Hasil penelitian:1) dokumen KA disusun oleh konsultan dengan jumlah tenaga akhli kurang dari yang disyaratkan sehingga konsultan tidak mampu menelaah secara cermat, holistik dan integral dalam menyusun dokumen ANDAL, (2) studi ANDAL cenderung kekurangan informasi komponen- lngkungan yang berdampak negatif dan positif terhadap lingkungan, (3) para konsultan penyusun RKL- RPL tidak mengetahui secara tepat komitmen dan mekanisme koordinasi yang mengikat secara kelembagaan dalam merencanakan pengelolaan lingkungan untuk mengurangi dampak negatif serta meningkatkan dampak positif. (4) produk AMDAL hanya menjadi dokumen yang disimpan tanpa sangsi jika indikatorindikator ANDAL, RKL dan RPL dilanggar.
\end{abstract}

Kata kunci : Evaluasi, AMDAL, KA, ANDAL, RKL, RPL

\section{PENDAHULUAN}

Perkembangan pembangunan di Kota Bandung diarahkan sebagai kota jasa, terutama setelah arus wisatawan baik domestik maupun mancanegara semakin meningkat. Hal ini disebabkan karena Kota Bandung memiliki beberapa sumber daya termasuk potensi pariwisata yang mampu meningkatkan pendapatan dan pertumbuhan 
ekonomi lokal. VillarinhoRosa and Haddad (2013) mengemukakan bahwa konsep pembangunan berkelanjutan memiliki makna meningkatkan kualitas hidup, yakni masyarakat dapat hidup di lingkungan yang sehat dengan keberlanjutan perbaikan keadaan sosial, ekonomis serta isu-isu lingkungan bagi generasi saat ini dan yang akan datang.

Faktanya pembangunan yang tidak terkendali di Kota Bandung hanya mengakomodasi prinsip politik dan ekonomis saja, lebih banyak menafikkan prinsip-prinsip ekologis. Ini terlihat pada tinginya tingkat pencemaran dan degradasi lingkungan yang tidak dapat dipertahankan. Selain itu bencana alam dari gempa tektonik, gempa vulkanik, banjir dan longsor menambah daftar panjang kerusakan lingkungan.

$\mathrm{Lu}, \mathrm{Wu}$ and Hsiung (2010) mengemukakan bahwa tujuan untuk mengantisipasi pembangunan yang rapat di perkotaan, struktur bawah tanah, seperti penggalian ke dalam tanah dan saluran air bawah tanah telah dilakukan untuk perluasan ruang bawah tanah. Pengetahuan dan pengalaman para insinyur dapat mengurangi atau menghindari kehancuran struktur bawah tanah melalui sistem informasi bangunan serta kajian analisis mengenai dampak lingkungan.

Hal ini mengisyaratkan bahwa AMDAL harus dapat dijadikan sebagai salah satu instrument untuk mitigasi bencana serta pelengkap bagi kelayakan teknis (soil investigastion dan rancangan struktur bangunan tinggi) pembangunan gedung tinggi di Kota Bandung. Li (2008) mengemukakan bahwa Environmental Impact Assessment (EIA) atau AMDAL adalah suatu proses yang awalnya dimulai di Amerika Serikat pada akhir tahun 1960-an dan awal 1970-an, telah diadopsi secara luas di seluruh dunia. Model EIA digunakan oleh negara-negara maju menyebarkan prinsipprinsip dasar dan kesepakatan pendekatan yang sama untuk masalah-masalah pembangunan yang mirip.

Fakta menunjukkan produk AMDAL hanya menjadi dokumen yang disimpan di perpustakaan saja tanpa sangsi jika indikatorindikator ANDAL, RKL dan RPL dilanggar. Masalah dalam penelitian ini dibatasi pada keterbatasan informasi: (1) acuan AMDAL pembangunan gedung 10 lantai hanya bersumber pada dokumen KA, (2) kajian dampak negatif dan positif pembangunan gedung 10 lantai hanya bersumber pada dokumen ANDAL proyek, (3) pengelolaan dan pemantauan dampak negatif serta positif hanya bersumber pada dokumen RKL-RPL proyek, (4) implementasi AMDAL hanya bersumber pada informasi para pemangku kepentingan yang tinggal di area batas proyek.

Tujuan penelitian adalah untuk: 1) mengevaluasi dokumen kerangka acuan (TOR-term of reference) pembangunan gedung 10 lantai, (2) mengevaluasi dokumen ANDAL pembangunan gedung 10 lantai, (3) mengevaluasi RKL dan RPL pembangunan gedung 10 lantai, (4) mengevaluasi implementasi AMDAL pembangunan gedung 10 lantai ditinjau dari ketepatan waktu, tindakan dan hasil guna untuk mengurangi dampak negatif serta meningkatkan dampak positif. Manfaat penelitian adalah : (1) memperoleh informasi dan model evaluasi dokumen AMDAL gedung 10 Lantai sebagai prototipe dalam mewujudkan prinsip pembangunan berkelanjutan yang mengakomodasikan aspek ekologis, ekonomis dan sosial politik, (2) naskah akademik untuk menyempurnakan peraturan dan perundangan untuk upayaupaya pembangunan berkelanjutan serta antisipasi penanggulangan bencana yang ditimbulkan akibat pembangunan gedung bertingkat tinggi, (3) menyempurnakan struktur program studi, kurikulum, peralatan, personel dan pendanaan yang lebih memiliki diversitas (keragaman) untuk memecahkan permasalahan yang lebih nyata dan bermakna bagi masyarakat sekitar, pemerintah dan pihak swasta dengan meningkatkan keunggulan komparatif (soft skill) dan keunggulan kompetitif (hard skill/teknologi) para civitas akademikanya.

\section{METODE PENELITIAN}

Metode pendekatan dengan deskriptif kualitatif melalui teknik analisis isi (content analysis). Penelitian dilaksanakan dari bulan April 2015-November 2015 dengan pengumpulan data primer dan sekunder. Rancangan penelitian Content analysis diawali dengan melakukan critical review terhadap standar teknis jenis data, pengolahan data dan keluaran komponen 
fisika, kimia, biologis dan sosial ekonomis yang tertulis pada KA atau TOR-term of reference.

Kombinasi content analysis dan consistency analysis menggunakan matriks dokumen ANDAL terhadap KA atau TOR yang telah ditetapkan pada tahap prakonstruksi, konstruksi dan pasca konstruksi ditelaah terkait dengan data yang dikumpulkan, teknik pengolahan data serta hasil keluaran yang dijadikan indikator keberhasilan ANDAL. Penelaahan dokumen RKL membahas tentang pihak-pihak yang bertanggung, aksi pengelolaan lingkungan yang akan dikelola dampak negatif dan positifnya serta indikator tingkat keberhasilan pengelolaan mengurangi dampak negatif serta meningkatkan dampak positifnya. Penelaahan dokumen RPL membahas tentang pihak-pihak yang bertanggung jawab, aksi pemantauan lingkungan yang akan dilakukan untuk menghambat dampak negatif yang akan muncul dan mendorong dampak positif. Diagram Alir Prosedur penilaian dokumen AMDAL merujuk pada Peraturan Menteri Negara Lingkungan Hidup Republik Indonesia Nomor 05 Tahun 2012 tersaji pada Gambar 1.

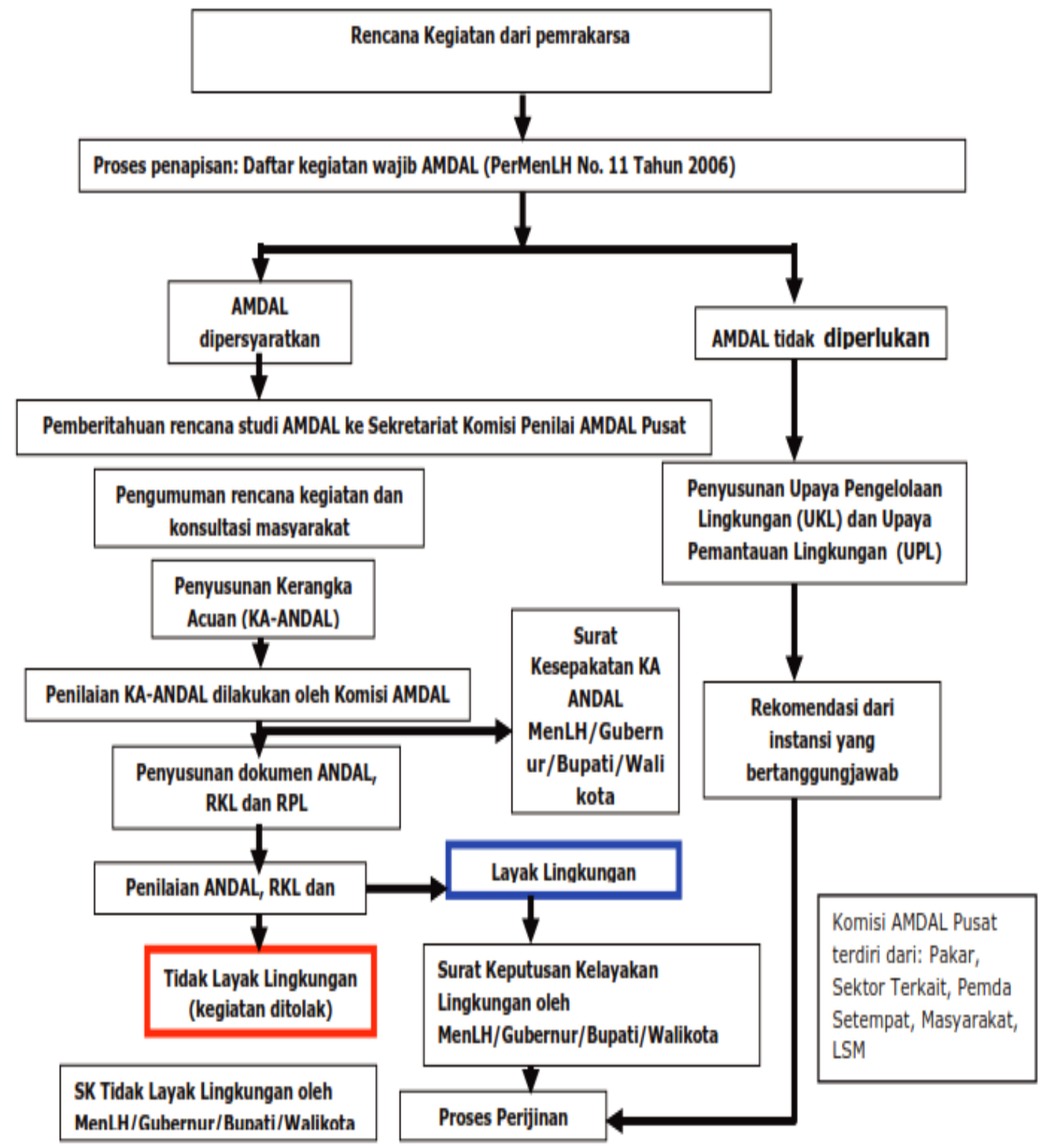

Gambar 1. Diagram Alir Prosedur AMDAL Berdasar PerMenLH Nomor 05 Tahun 2012

\section{HASIL DAN PEMBAHASAN}

Evaluasi dokumen AMDAL dengan studi kasus Pembangunan Hotel dan pertokoan Pasar Baru Square di Kota Bandung menunjukkan bahwa dokumen AMDAL disusun secara tidak cermat dan 
holistik, pada akhirnya pembangunan hotel dan pertokoan ini menjadi kegiatan yang dapat menghambat upaya mewujudkan pembangunan lestari yang berwawasan lingkungan serta tidak dapat menunjang program pemerintah daerah dalam mengupayakan peningkatan laju pertumbuhan ekonomi serta turut mendukung penciptaan image Kota Bandung sebagai Kota Jasa yang Bersih, Makmur, Taat dan Bersahabat.

Hasil evaluasi dokumen KA berdasar menunjukkan bahwa dokumen KA ini telah disusun oleh pemrakarsa yang bertanggung jawab atas usaha atau kegiatan Lokasi rencana usaha kegiatan sudah sesuai dengan rencana tata ruang. Pemrakarsa meminta bantuan kepada pihak lain yang tergabung dalam lembaga penyedia jasa penyusunan dokumen AMDAL. Evaluasi menujukkan konsultan ini tidak mantap karena jumlah tenaga ahli yang nyata bekerja menyusun KA selain kurang dari yang disyaratkan juga tidak memiliki sertifikat kompetensi AMDAL. Padahal penyusun AMDAL seharusnya wajib memiliki sertifikat kompetensi yang diperoleh melalui uji kompetensi setelah mengikuti pendidikan dan pelatihan penyusunan pada lembaga pelatihan bidang AMDAL dan dinyatakan lulus. Uji kompetensi dan penerbitan sertifikat kompetensi dilaksanakan oleh lembaga sertifikasi kompetensi penyusun AMDAL yang ditunjuk oleh Menteri.

Pemrakarsa, dalam menyusun dokumen AMDAL telah mengikutsertakan masyarakat yang terkena dampak melalui konsultasi publik yang dilakukan sebelum penyusunan dokumen KA. Tsai and Yang (2010) mengemukakan bahwa para pengelola proyek memperkecil resiko kegagalan dengan menandatangani kontrak dengan para pemilik bangunan, seperti skema kontrak perancangan dan pembangunan atau pembangunan perancangan bagi sistem penyerahan proyek sebagai cara memindahkan atau menyerahkan resiko kepada pihak lain.

Dokumen KA seharusnya disusun oleh Pemrakarsa pada tahap perencanaan kegiatan tetapi faktanya penyusunan KA ANDAL disusun bersamaan dengan kegiatan pembangunan. Proses identifikasi dampak potensial (tabel 2.6) tidak dikaji secara mendalam, terdapat pertentangan antara isi dengan tabel 2.7, beberapa data tidak terbaharui, isi bahasan berbeda lokasi kajian, terdapat copy paste data proyek yang berbeda dengan berbagai macam alasan finansial, waktu dan lain sebagainya. Hasil evaluasi Dokumen KA tertera pada Tabel 1.

Hasil evaluasi dokumen ANDAL Pembangunan Hotel dan Pertokoan menunjukkan pemrakarsa menyusun dokumen ANDAL berdasarkan konsep dimana Komisi Penilai AMDAL belum menerbitkan persetujuan KA. Prakiraan dampak penting tidak secara cermat dilakukan untuk masing- masing alternatif terlihat masih kurangnya alternatif relokasi PKL setempat, penggunaan alat-alat berat selama masa konstruksi yang mengganggu lingkungan sekitar, serta kuantitas air bersih yang mengganggu PDAM masyarakat terkena dampak.

Tabel 1. Resume Evaluasi Dokumen Kerangka Acuan

\begin{tabular}{lll}
\hline No & \multicolumn{1}{c}{ Hal Yang Diperhatikan } & \multicolumn{1}{c}{ Hasil Penilaian } \\
\hline 1. & $\begin{array}{l}\text { Alasan rencana usaha dan/atau kegiatan ini wajib memiliki AMDAL } \\
\text { dan pendekatan studi yang digunakan (tunggal, terpadu, atau } \\
\text { kawasan) }\end{array}$ & $\begin{array}{l}\text { Ada tetapi tidak secara detail } \\
\text { pasal dan ayat serta besaran }\end{array}$ \\
2. $\quad \begin{array}{l}\text { Alasan mengapa rencana usaha kegiatan dinilai KPA Pusat, } \\
\text { Provinsi, atau Kabupaten / Kota }\end{array}$ & Tidak ada \\
3 $\quad \begin{array}{l}\text { Uraian umum maupun rinci mengenai tujuan dilaksanakanya } \\
\text { rencana usaha dan/atau kegiatan }\end{array}$ & Tidak rinci \\
4. $\quad \begin{array}{l}\text { Siapa yang bertindak sebagai pelaksana studi AMDAL? } \\
\text { 5. }\end{array}$ & $\begin{array}{l}\text { Status studi AMDAL apakah d.ilaksanakan terintegrasi, bersamaan } \\
\text { atau setelah studi kelayakan teknis dan ekonomis? } \\
\text { Dalam Pelingkupan telah disajikan informasi mengenai Analisis } \\
\text { Hasil pelibatan masyarakat }\end{array}$ & $\begin{array}{l}\text { Tidak sengan CV } \\
\text { Dilakukan secara bersamaan }\end{array}$ \\
& & $\begin{array}{l}\text { Ada tetapi beberapa tidak } \\
\text { menjadi DPH }\end{array}$ \\
\hline
\end{tabular}


Tidak dilakukan evaluasi secara holistik terhadap dampak lingkungan dan tidak menguraikan hasil evaluasi telaahan keterkaitan atau interaksi seluruh dampak penting hipotetik (DPH) rencana usaha secara total. Tidak terdapat kesimpulan kelayakan atau ketidaklayakan lingkungan hidup berupa prakiraan secara cermat mengenai besaran dan sifat penting dampak dari aspek bio-geofisik, kimia, sosial, ekonomi, budaya, tata ruang, dan kesehatan masyarakat pada tahap pra-konstruksi, konstruksi, operasi, dan pasca operasi kegiatan yang diprakirakan timbul dampak penting dari gedung bertingkat tinggi. Evaluasi menunjukkan tidak terdapat analisis mengenai kesimpulan kelayakan dari sisi kepentingan pertahanan keamanan negara sesuai dengan ketentuan peraturan perundang- undangan. Resume Hasil evaluasi dokumen ANDAL tertera pada Tabel 2.

Hasil evaluasi dokumen RKL-RPL menunjukkan kolom bentuk kelola lingkungan hidup pada matriks RKL tidak secara lengkap menguraikan resiko dan metode yang akan digunakan untuk mengelola dan memantau resiko dampak lingkungan. Taroun, Yang and Lowe (2011) menyatakan bahwa penilaian resiko merupakan komponen tersulit dari proses pengelolaan resiko, yang paling digunakan pada penilaian pembangunan. Penggunaan komponen resiko sebagai ukuran yang sering digunakan dengan kerangka suatu keputusan yang dianut dapat menjadi suatu pemecahan masalah yang inovatif sehingga menjadi masukan umum memperbaiki penilaian resiko pembangunan konstruksi.

Tabel 2. Resume Evaluasi Dokumen ANDAL

\begin{tabular}{clc}
\hline No & \multicolumn{1}{c}{ Hal yang Dinilai/Diperiksa } & Hasil Penilaian \\
\hline 1. & $\begin{array}{l}\text { Prakiraan dampak penting dilakukan memperhatikan dampak yang } \\
\text { bersifat langsung dan/atau tidak langsung }\end{array}$ & Tidak \\
2. & $\begin{array}{l}\text { Prakiraan dampak penting dilakukan untuk masing- alternatif, dan/atau kegiatan } \\
\text { masih berada pada tahap pemilihan alternatif komponen Rencana usaha } \\
\text { Terdapat kesimpulan kelayakan ingkungan hidup dari rencana kegiatan terhadap } \\
\text { kriteria kelayakan lingkungan hidup berupa kepentingan pertahanan keamanan }\end{array}$ & Tidak lengkap \\
& $\begin{array}{l}\text { Negara } \\
\text { Analisis kelayakan lingkungan hidup berupa Prakiraan secara cermat mengenai } \\
\text { besaran dan sifat penting dampak dari aspek bio-geofisik, kimia, sosial, } \\
\text { ekonomi, budaya, tata ruang, kesehatan masyarakat }\end{array}$ & $\begin{array}{c}\text { Tidak secara } \\
\text { cermat }\end{array}$ \\
\hline
\end{tabular}

Rencana mengelola resiko dampak menunjukkan: (a) bahwa pengumpulan dan analisis data tidak konsisten dengan metode yang digunakan disaat penyusunan ANDAL, (b) tidak didukung dengan gambaran lokasi pemantauan yang tepat disertai dengan peta lokasi pemantauan berskala yang menunjukkan lokasi pemantauan dimaksud, (c) tidak secara cermat menguraikan tentang jangka waktu atau lama periode pemantauan berikut dengan frekuensinya per satuan waktu. Resume evaluasi dokumen RKL-RPL tersaji pada Tabel 3.

Tabel 3. Resume Evaluasi Dokumen RKL dan RPL

\begin{tabular}{|c|c|c|}
\hline No & Hal Yang Dinilai/Diperiksa & Hasil Penilaian \\
\hline 1 & $\begin{array}{l}\text { Kolom Dampak lingkungan pada matriks RKL telah diuraikan } \\
\text { dampak yang terjadi akibat rencana kegiatan }\end{array}$ & $\begin{array}{l}\text { Terdapat kesalahan pada hasil } \\
\text { pelingkupan }\end{array}$ \\
\hline 2 & $\begin{array}{l}\text { Dampak lingkungan hidup yang di sampaikan konsisten/relevan } \\
\text { dengan hasil pelingkupan KA dan kajian pada ANDAL }\end{array}$ & $\begin{array}{l}\text { Terdapat kesalahan pada hasil } \\
\text { pelingkupan }\end{array}$ \\
\hline 3 & $\begin{array}{l}\text { Sumber dampaknya konsisten/relevan dengan penjelasan } \\
\text { sebelumnya pada KA dan ANDAL }\end{array}$ & $\begin{array}{l}\text { Terdapat kesalahan pada hasil } \\
\text { pelingkupan }\end{array}$ \\
\hline 4 & $\begin{array}{l}\text { Kolom sumber dampak pada matriks/tabel RKL telah } \\
\text { diuraikan mengenai Komponen kegiatan penyebab Dampak } \\
\text { secara singkat }\end{array}$ & $\begin{array}{l}\text { Terdapat kesalahan pada hasil } \\
\text { pelingkupan }\end{array}$ \\
\hline 5 & $\begin{array}{l}\text { Kolom Bentuk Pemantauan pada matriks RPL diuraikan secara } \\
\text { singkat mengenai metode yang akan digunakan untuk memantau } \\
\text { indikator/parameter dampak lingkungan }\end{array}$ & lengkap \\
\hline
\end{tabular}




\section{KESIMPULAN DAN SARAN}

\section{Kesimpulan}

- Implementasi dokumen AMDAL menjadi parameter paling peka terhadap keberhasilan kelayakan lingkungan

- Dokumen KA disusun oleh para konsultan tidak mantap karena jumlah tenaga ahli yang menyusun KA kurang dari yang disyaratkan.

- Penyusunan studi ANDAL cenderung kekurangan informasi komponen lingkungan yang berdampak negatif dan positif terhadap lingkungan karena para konsultan bekerja terburu-buru dibatasi oleh waktu serta biaya yang meningkat tidak terduga.

- Identifikasi komponen lingkungan tidak mengacu pada studi-studi ANDAL pembangunan gedung tinggi yang serupa atau dari hasil diskusi dengan para pemangku kepentingan saat penyajian KA dalam bentuk laporan pendahuluan (inception report).

- Penyusun RKL dan RPL tidak mengetahui secara tepat komitmen serta mekanisme koordinasi yang mengikat secara kelembagaan.

- Produk AMDAL hanya menjadi dokumen yang disimpan di perpustakaan saja tanpa sangsi jika indikator-indikator KA, ANDAL, RKL dan RPL dilanggar.

\section{Saran}

- KPA dapat menyatakan dokumen AMDAL perlu diperbaiki dan mengembalikan kepada pemrakarsa dengan pertimbangan: (a) prakiraan besaran dan sifat penting dampak, (b) hasil evaluasi secara holistik terhadap seluruh DPH, (c) kemampuan pemrakarsa atau pihak terkait dalam menanggulangi dampak penting negatif.

- Walikota tidak begitu saja menetapkan keputusan kelayakan atau ketidaklayakan lingkungan hidup karena diberikan jangka waktu penetapan keputusan.

- Perlu Pengembangan Modul Latih Evaluasi Dokumen AMDAL yang efisien dan efektif dalam meningkatkan kompetensi penilai AMDAL.

\section{DAFTAR PUSTAKA}

Anonimous. 2012, Peraturan Menteri Negara Lingkungan Hidup Republik Indonesia Nomor 05 Tahun 2012 tentang Jenis Rencana Usaha dan Kegiatan yang Wajib Memiliki Analisis Mengenai Dampak Lingkungan Hidup. Kementerian Lingkungan Hidup. Jakarta.

Anonimous. 2012, Peraturan Menteri Negara Lingkungan Hidup Republik Indonesia Nomor 06 Tahun 2012 tentang Pedoman Penyusunan Dokumen Lingkungan Hidup.. Kementerian Lingkungan Hidup. Jakarta.

Lu, S.R. and B.C.B. Hsiung. 2010. Applying building information modeling in environmental impact assessment for urban deep excavation projects. Department of Civil Engineering, National Kaohsiung University of Applied Sciences Kaohsiung, Taiwan. kwu@ kuas.edu.tw.

Li, J.C. 2008. Environmental Impact Assessment in Developing Countries: An Opportunity for Greater Environmental Security?. Working Paper No 4. USAID and Foundation for Environmental Security \& Sustainability.

Taroun, A., J.B. Yang and D.Lowe. 2011. Construction Risk Modeling and Assessment: Insights from a Literature Review. The Build \& Human Environment Review Volume 4, Special Issue 2011. United Kingdom.

Tsai, T.C. and M.L. Yang. 2010. Risk Assessment of Design-Bid-Build and Design-Build Building Projects. Journal of the Operations Research Society of Japan Vol 53 No 1 Macrh 2010 pp 20-30.

Villarinho Rosa, I. and A.N. Haddad. 2013. Building Sustainability Assessment throughout Multicriteria Decision Making. Journal of Construction Engineering Volume 2013 Article ID578671.

Http://dx.doi.org/10.1155/2013/57867 1. Hindawi Publishing Corporation. 